\title{
THE CORRELATION BETWEEN TERPENOID OF SARANG SEMUT (Myrmecodia pendans) WITH mRNA FRUCTOSYLTRANFERASE EXPRESSION OF Streptococcus mutans BIOFILM ATCC 25175
}

Darul Rabil', Eka Chemiawan ${ }^{* *}$, Mieke H. Satari" ${ }^{* * *}$ Meirina Gartika ${ }^{* *}$

${ }^{*}$ Resident of Pediatric Dentistry Department, Faculty of Dentistry, Universitas Padjadjaran

** Lecturer of Pediatric Dentistry Department, Faculty of Dentistry, Universitas Padjadjaran

${ }^{* * *}$ Lecturer of Oral Biology, Faculty of Dentistry, Universitas Padjadjaran

Correspondence : meirina.gartika@fkg.unpad.ac.id

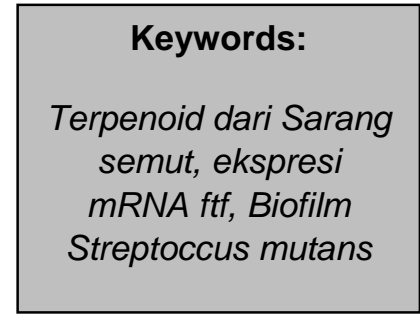

\section{PENDAHULUAN}

Salah satu bakteri dominan penyebab
karies adalah Streptococcus mutans yang
memiliki kemampuan membentuk biofilm gigi. ${ }^{1}$
Survei epidemiologi menunjukkan bahwa
jumlah S. mutans lebih besar pada anak-anak. ${ }^{2}$

Salah satu bakteri dominan penyebab
karies adalah Streptococcus mutans yang
memiliki kemampuan membentuk biofilm gigi. ${ }^{1}$
Survei epidemiologi menunjukkan bahwa
jumlah S. mutans lebih besar pada anak-anak. ${ }^{2}$

Salah satu bakteri dominan penyebab
karies adalah Streptococcus mutans yang
memiliki kemampuan membentuk biofilm gigi. ${ }^{1}$
Survei epidemiologi menunjukkan bahwa
jumlah S. mutans lebih besar pada anak-anak. ${ }^{2}$

Salah satu bakteri dominan penyebab
karies adalah Streptococcus mutans yang
memiliki kemampuan membentuk biofilm gigi. ${ }^{1}$
Survei epidemiologi menunjukkan bahwa
jumlah S. mutans lebih besar pada anak-anak. ${ }^{2}$

Salah satu bakteri dominan penyebab
karies adalah Streptococcus mutans yang
memiliki kemampuan membentuk biofilm gigi. ${ }^{1}$
Survei epidemiologi menunjukkan bahwa
jumlah S. mutans lebih besar pada anak-anak. ${ }^{2}$

\begin{abstract}
Background: Terpenoid isolate sarang semut (Myrmecodia pendans) is a natural material that has antibacterial power through the destruction of the cell membrane of Streptoccus mutans (S. mutans). Fructosiltransferase (ftf) is one of the extrapolisaccharides produced by S. mutans. The formation of Ftf is governed by the ftf gene. The aim of research was to know the correlation between terpenoid of Sarang semut administration with ftf mRNA expression of S. mutans biofilm ATCC 25175.

Method: The study used mixed methods, namely descriptive explorative method to look at the isolation of ftf gene and ftf mRNA expression. This study began with making 1 day biofilm, then given terpenoid isolates of sarang semut and chlorhexidine. Next, isolation of ftf genes and ftf $m R N A$ expression was carried out, then the differences in S. mutans ATCC 25175 mRNA ftf expression in sarang semut and chlorhexidine were given for 1 and 30 minutes using Real-Time PCR. Continued by looking at the relationship of the duration of administration of sarang semut terpenoids to the expression of S. mutans ATCC 25175 mRNA ftf biofilm. Statistical analysis used the $t$ test with $p$-value $<0.05$ and Pearson.

Results: The results showed that ftf gene with $130 \mathrm{bp}$ length and ftf $m R N A$ expression could be isolated from $S$. mutans biofilm ATCC 25175 which were given terpenoid isolates from sarang semut. The expression of sarang semut mRNA ftf and chlorhexidine did not have a significant difference for 1 minute $(p=0.0761)$, whereas in 30 minutes the ant nest had a higher mRNA expression $(p=0.0186)$. There is a relationship between the duration of administration of terpenoid isolates of sarang semut with $S$. mutans ATCC 25175 mRNA ftf expression $(r 2=0.614)$, with a medium correlation coefficient.

Conclusion: The conclusion of the study were that sarang semut terpenoid had the same effect as chlorhexidine for 1 minute on S. mutans biofilms, whereas at 30 minutes it was different. There is a relationship between terpenoids of sarang semut isolates and $S$. mutans biofilm ATCC 25175 mRNA expression.
\end{abstract}

Kondisi ini berhubungan dengan nilai dmf-t yang lebih tinggi. ${ }^{3}$

Salah satu virulensi bakteri penyebab karies gigi adalah kemampuannya untuk bertahan hidup dalam lingkungan rongga mulut 
yang kompleks. S. mutans membentuk biofilm dengan organisme lain dalam rongga mulut. ${ }^{4}$ Penelitian menunjukkan bahwa bakteri yang tumbuh pada kondisi biofilm lebih tahan terhadap antibiotik daripada planktonik. Biofilm merupakan bentuk struktural sekumpulan mikroorganisme yang dilindungi oleh matriks ekstraseluler yang disebut ekstrapolisakarida (EPS). ${ }^{5}$

Polisakarida yang diproduksi oleh $S$. mutans adalah bagian utama matriks biofilm dan berfungsi dalam patogenitasnya. ${ }^{6,7} S$. mutans berikatan dengan kuat pada permukaan berlapis glukan dan tumbuh subur di lingkungan mulut yang kompleks dan berubah menjadi biofilm kariogenik. Glukan merupakan salah satu polisakarida yang disintesis oleh $S$. mutans dengan bantuan glukosiltransferase (Gtf).8,9

Selain menghasilkan Gtf, S. Mutans memproduksi fruktosiltransferase (Ftf), yang mengubah fruktosa menjadi fruktan. Frutosyltransfearase berfungsi sebagai sumber energi sehingga dapat digunakan selama metabolisme. ${ }^{10}$ Hal ini menyebabkan $\mathrm{ftf}$ memiliki peran dalam pembentukan biofilm. ${ }^{11}$

Proses pembentukan awal biofilm memerlihatkan bahwa berbagai gen diperlukan S. mutans untuk beradaptasi. Setiap enzim diatur oleh gen nya seperti glucosyltransferase ( $g t f$ dan fructosyltransferase ( $f t f$ ). Sel yang ada dalam biofilm memiliki karakteristik fenotip berbeda yang disertai dengan perubahan signifikan dalam pola ekspresi gen. Ekspresi gen ini termasuk gen yang terkait dengan sistem komunikasi interseluler, sistem penginderaan lingkungan, regulator metabolisme karbohidrat, dan gen yang mempromosikan adhesi. ${ }^{12}$ Ekspresi gtf pada biofilm semakin lama akan meningkat sedangkan $\mathrm{ftf}$ sebaliknya. ${ }^{13}$

Saat ini banyak penelitian bahan alam yang dapat menghambat pertumbuhan salah satunya adalah sarang semut (Myrmecodia pendans). ${ }^{14}$ Sarang semut telah lama dikenal sebagai bahan pengobatan, diantaranya digunakan untuk berbagai jenis kanker dan tumor, seperti kanker otak, hidung, payudara, lever, paru-paru, usus, rahim, kulit, prostat, dan kanker darah. ${ }^{15}$ Tujuan penelitian ini untuk mengetahui apakah terdapat hubungan pemberian terpenoid isolat sarang semut terhadap ekspresi mRNA ftf dari biofilm $S$. mutans ATCC 25175.

\section{METODE}

Penelitian ini dilakukan di Institut Teknologi Bandung dengan persetujuan etik no. 336/UN6.KEP/EC/2019 yang dikeluarkan oleh Komisi Etik Penelitian Kementrian Riset, Teknologi, dan Pendidikan Tinggi Universitas Padjadjaran. Pertama, dilakukan pembuatan biofilm S. mutans ATCC 25175 berumur 1 hari dan selanjutnya diberi terpenoid isolat sarang semut selama 1 dan 30 menit. Selanjutnya dilakukan isolasi gen $\mathrm{ftf}$ dan pemeriksaan ekspresi mRNA ftf dari biofilm S. mutans ATCC 25175 menggunakan Real-Time PCR. Penelitian ini menggunakan 16SrRNA sebagai housekeeping gene. Replikasi pada penelitian ini dilakukan sebanyak 5 kali. Analisis statistik menggunakan uji t berpasangan untuk melihat perbedaan ekspresi mRNA biofilm $S$. mutans ATCC 25175 antara pemberian terpenoid sarang semut selama 1 dan 30 menit dan uji Pearson dengan $p$-value $<0.05$. Seluruh analisis dilakukan menggunakan program statistik Excel Megastat. 
Tabel 1. Urutan primer dari gen ftf dan 16SrRNA

\begin{tabular}{cc}
\hline \multirow{2}{*}{ Gen } & \multicolumn{1}{c}{ Deskripsi } \\
\hline \multirow{2}{*}{ Ftf } & Forward 5' AAATATGAAGGCGGCTACAACG 3' \\
\cline { 2 - 2 } & Reverse 5' CTTCACCAGTCTTAGCATCCTGAA 3' \\
\cline { 2 - 2 } 16sRNA & Forward 5' CTTACCAGGTCTTGACATCCCG 3' \\
\cline { 2 - 2 } & Reverse 3' ACCCAACATCTCACGACACGAG 3' \\
\cline { 2 - 2 } &
\end{tabular}

HASIL

Pemeriksaan PCR (non-purified) dengan gen target 16SrRNA dan ftf. dilakukan menggunakan jasa Macrogen, Inc. Hasil PCR gen 16SrRNA ditunjukkan dalam Gambar 1.



Gambar 1 menunjukkan hasil isolasi gen 16SrRNA yaitu adanya pita. dalam setiap bahan yang diperiksa. Gen 16SrRNA merupakan gen kontrol yang menunjukkan bahwa bahan yang diperiksa merupakan bakteri. Dari hasil pemeriksaan PCR gen 16SrRNA memiliki panjang 103 pasang basa. 


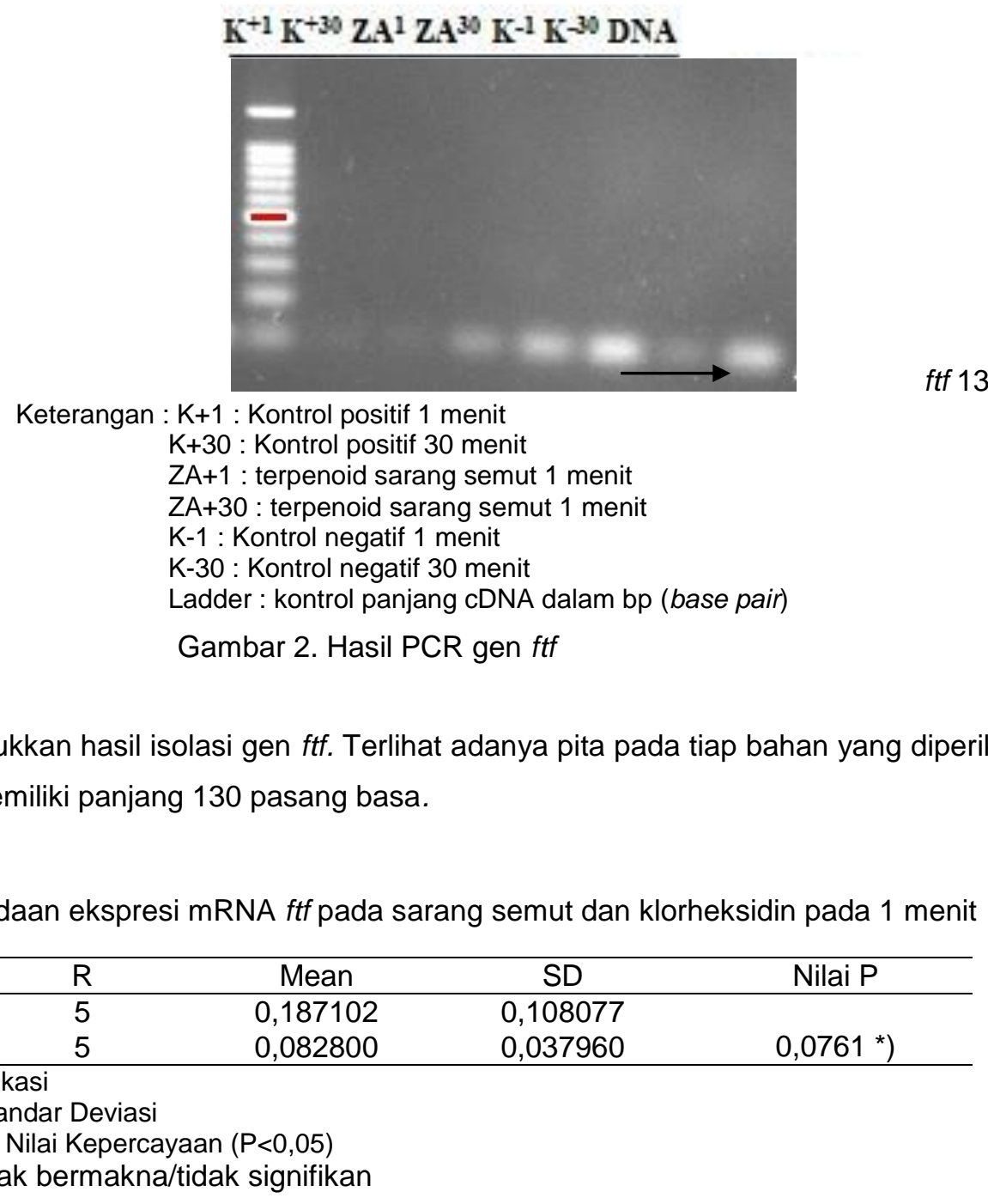

Gambar 2 menunjukkan hasil isolasi gen ftf. Terlihat adanya pita pada tiap bahan yang diperiksa. Gen ftf yang terlihat memiliki panjang 130 pasang basa.

Tabel 2. Uji Perbedaan ekspresi mRNA ftf pada sarang semut dan klorheksidin pada 1 menit

\begin{tabular}{ccccc}
\hline Bahan uji & $\mathrm{R}$ & Mean & SD & Nilai P \\
\hline Sarang semut & 5 & 0,187102 & 0,108077 & \\
Klorheksidin & 5 & 0,082800 & 0,037960 & $\left.0,0761^{*}\right)$ \\
\hline Keterangan :R : replikasi & & & \\
SD : Standar Deviasi & & & \\
Nilaa $\mathrm{p}$ : Nilai Kepercayaan $(P<0,05)$ & & \\
* $)$ : Tidak bermakna/tidak signifikan &
\end{tabular}

Tabel 2 menunjukkan tidak terdapat perbedaan yang signifikan ekspresi mRNA ftf antara pemberian sarang semut dan klorheksidin pada biofilm S. mutans ATCC 25175 dalam pemeriksaan 1 menit (nilai $p=0,0761$ ). Hasil ini memiliki makna bahwa pemberian sarang semut dan klorheksidin selama 1 menit memiliki efek yang sama terhadap ekspresi mRNA ftf.

Tabel 3. Uji perbedaan ekspresi mRNA ftf pada sarang semut dan klorheksidin pada 30 menit

\begin{tabular}{clccc}
\hline Bahan uji & $\mathrm{R}$ & Mean & $\mathrm{SD}$ & Nilai P \\
\hline Sarang semut & 5 & 1,238415 & 0,650277 & \\
Klorheksidin & 5 & 0,342674 & 0,565886 & $\left.0,0185^{\star *}\right)$ \\
\hline
\end{tabular}

\footnotetext{
Keterangan : $\mathrm{R}$ : replikasi

SD : Standar Deviasi

Nilai $p$ : Nilai Kepercayaan $(P<0,05)$

$\left.{ }^{\star *}\right)$ : Bermakna/signifikan
}

Tabel 3 menunjukkan terdapat perbedaan yang signifikan ekspresi mRNA ftf pada biofilm $S$. mutans antara pemberian sarang semut dan klorheksidin selama 30 menit (nilai $p=0,0185$ ). Hasil ini 
memiliki makna bahwa sarang semut dan klorheksidin selama 30 menit memiliki efekyang berbeda terhadap ekspresi mRNA ftf.

Tabel 4. Uji korelasi terpenoid sarang semut dengan ekspresi mRNA ftf

\begin{tabular}{cccccc}
\hline Variabel & $R$ & t-test & $p$-value & sifat & $r^{2}$ \\
\hline Waktu \& ftf &, 783 & 1,56 & 0,0073 & Non-Sign &, 614 \\
\hline
\end{tabular}

Tabel 4 menunjukkan bahwa terdapat hubungan yang positif lamanya pemberian terpenoid sarang semut (Myrmecodeia pendans) terhadap peningkatan ekspresi mRNA ftf pada biofilm Streptococcus mutans ATCC 25175. Hubungan yang signifikan tersebut ditunjukkan dengan nilai keterkaitan sebesar 0,614. Korelasi ini dapat diinterpretasikan dalam kriteria Guilford, hasil tersebut memiliki reliabilitas sedang.

\section{DISKUSI}

Penelitian ini menunjukkan gen $\mathrm{ftf}$ dan ekspresi mRNA ftf dapat diisolasi pada biofilm S. mutans yang diberi isolat terpenoid sarang semut (Myrmecodia pendans). Isolasi gen ftf yang terlihat merupakan hasil dari proses PCR yang memperlihatkan DNA yang akan diperiksa, sedangakn ekspresi mRNA ftf merupakan hasil proses Real Time PCR. Hasil ini sesuai dengan penelitian yang dilakukan $\mathrm{Li}$ et al ${ }^{17}$ bahwa gen $\mathrm{ftf}$ dapat terisolasi dan terekspresi pada biofilm yang diberi kurkumin. Lamanya pemberian curcumin berpengaruh terhadap peningkatan ekspresi gen ftf.

Penelitian yang dilakukan Gartika et al ${ }^{18}$ menjelaskan bahwa pemberian terpenoid sarang semut selama 1 menit dapat menghancurkan $40 \%$ biofilm yang terbentuk. Burne et $\mathrm{al}^{19}$ menggunakan analisis chloramphenicol acetiltransferase (CAT), terlihat ekspresi ftf pada biofilm berumur 2 hari, kemudian diberikan $0.025 \mathrm{~mol} / \mathrm{L}$ sukrosa sehingga menunjukkan peningkatan ekspresi dari menit 0 ke 10 . Hasil yang sama terlihat pada pemeriksaan biofilm yang berumur 7 hari.
Fruktan dapat memengaruhi patogenesis karies gigi dengan fungsinya sebagai penyimpanan karbohidrat ekstraseluler dan dapat dimetabolisme oleh bakteri selama periode kekurangan nutrisi. Fruktosa yang dilepaskan dari hidrolisis fruktan dapat memasuki siklus glikolitik dan dimetabolisme menjadi asam laktat, yang dapat menyebabkan demineralisasi permukaan email gigi dan berkontribusi terhadap pembentukan karies gigi. ${ }^{20}$ Siklus glikolitik merupakan proses metabolisme glukan menjadi asam laktat. Saat ini, terbukti bahwa fruktan membantu proses adhesi bakteri oral tertentu ke permukaan gigi. Ftf bebas juga ditemukan menyerap ke dalam lapisan glukan $S$. mutans dan membantu sintesis glukan oleh Gtf bebas. ${ }^{21} \mathrm{Ftf}$ dan produknya (fruktan) berperan dalam pembentukan biofilm gigi dan berhubungan dengan proses karies gigi. ${ }^{22}$

Penelitian Rozen et al ${ }^{21}$ menunjukkan jumlah rendah ftf bebas di luar sel ketika $S$. mutans dibiakkan dengan penambahan sukrosa. Tingkat ftf yang rendah ini, ditemukan sebagai hasil dari adsorpsi ftf bebas di luar sel 
ke S. mutans yang dilapisi glukan, yang terbentuk selama pertumbuhan dengan adanya sukrosa. Berbeda dengan temuan lain, Milward dan Jacques ${ }^{23}$ menunjukkan pelepasan cepat $\mathrm{ftf}$ pada permukaan sel Stretococcus salivarius setelah penambahan sukrosa. ${ }^{21}$

Sekresi ftf yang mengekspresikan pengikatan glukan oleh $S$. mutans dapat memberikan keuntungan dalam biofilm gigi. Temuan Rozen et al ${ }^{20}$ menunjukkan bahwa fruktan dapat mempromosikan proses adhesi bakteri spesifik ke permukaan yang keras. ${ }^{20}$ Adhesi fruktan dapat dimediasi melalui pengikat fruktan atau pada enzim Ftf. Identifikasi mengenai pengikat fruktan tersebut masih harus dieksplorasi. Pengikatan ftf dengan glukan juga dapat meningkatkan retensi $S$. mutans ke permukaan yang dilapisi glukan dengan menjembatani antara glukan. ${ }^{21}$

Sukrosa juga dapat membantu peningkatan sintesis fruktan pada permukaan S.mutans. Kemampuan S. mutans untuk menghasilkan fruktan dalam jumlah tinggi menyebabkan adanya senyawa karbohidrat jangka pendek yang dapat meningkatkan kelangsungan hidup bakteri selama periode kekurangan nutrisi dalam biofilm. Fruktosa yang dilepaskan dari hidrolisis fruktan dapat dimanfaatkan oleh bakteri dan menghasilkan asam laktat, sehingga berkontribusi terhadap perkembangan karies gigi. Selain itu, jumlah tinggi fruktan yang diproduksi $S$. mutans juga dapat meningkatkan virulensi bakteri dengan berperan sebagai bahan kapsul yang dapat melindunginya dari sistem kekebalan tubuh. ${ }^{24}$

Tingkat ekspresi ftf dalam biofilm dengan $\mathrm{pH}$ rendah tidak meningkat seperti dalam biofilm yang terbentuk dengan media yang ditambahkan zat tertentu. Populasi $S$. mutans tergantung dengan adanya sukrosa sebagai penginduksi efisien dari ekspresi gen ftf. Namun, penambahan glukosa ke biofilm hanya memiliki efek sedikit pada gen $\mathrm{ftf}$. Dalam kultur kimia yang stabil, dengan menurunkan $\mathrm{pH}$ dari 7 menjadi 6 , dapat meningkatkan transkripsi ftf, sehingga faktor ini cenderung memiliki efek pada ftf setelah penambahan karbohidrat. Dengan demikian, faktor global yang mengatur ekspresi gen dalam kaitannya dengan aliran karbohidrat atau $\mathrm{pH}$ dapat tumpang tindih dengan regulator yang mengontrol transkripsi $f t f^{13,11}$

Penelitian Abranches et $\mathrm{a}^{25}$ menemukan bahwa Catabolite Control Protein $A(\mathrm{CcpA})$ berperan dalam penentuan virulensi. Hal ini menunjukkan bahwa gen gtfB dan ftf memerlukan CcpA untuk ekspresi optimal. Berdasarkan studi genetik, percobaan biokimia dan fisiologis menunjukkan bahwa hilangnya CcpA berdampak pada kemampuan S. mutans untuk transportasi dan pertumbuhan. ${ }^{25}$

Diketahui ekstrak kasar sarang semut tergolong concentration-dependent atau dapat juga disebut memiliki antibakteri yang fungsinya tergantung dari konsentrasi bahan. Antibakteri golongan ini memiliki perbedaan antara efek maksimum dan minimum yang relatif besar dan dengan peningkatan konsentrasi akan meningkatkan kemampuan bunuh terhadap bakteri. ${ }^{26}$ Efek antibakteri yang optimal dari concentration-dependent bergantung pada luas area di bawah kurva penghambatan yang disederhanakan menjadi rasio antara konsentrasi optimal. 27

Ekstrak, fraksi, maupun isolat umbi sarang semut telah terbukti selain mempunyai aktivitas antibakteri juga memiliki aktivitas antioksidan, imun modulator, dan antikanker. Penelitian sebelumnya ditemukan bahwa ekstrak etil asetat dari $M$. pendans dapat 
menghambat pertumbuhan $S$. mutans.

Senyawa terpenoid termasuk diterpenoid, monoterpenoid, dan sesquiterpenoid dilaporkan memiliki banyak aktivitas antibakteri dan antimikroba. ${ }^{28}$

Terpenoid dari sarang semut adalah hasil maserasi sarang semut dari bagian umbi dan memiliki daya antibakteri. Penelitian sebelumnya menunjukkan bahwa terpenoid sarang semut memiliki nilai MBIC (Minimum Biofilm Inhibitory Concentration) terpenoid dari sarang semut terhadap biofilm $S$. mutans adalah $50 \mathrm{ppm}$, dan nilai MIC (Minimum Inhibitory Concentration) adalah 40 ppm. ${ }^{18}$ Penelitian Attamimi et al ${ }^{15}$ menunjukkan bahwa ekstrak kasar umbi sarang semut memiliki nilai MIC antara 9,77 ppm dan 19,53 ppm. ${ }^{15}$

Penelitian ini menunjukkan adanya hubungan yang positif lamanya pemberian terpenoid isolate sarang semut dengan gen $\mathrm{ftf}$ pada biofilm S. mutans ATCC 25175. Disamping itu penelitian ini dilakukan pada kondisi biofilm yang menyulitkan senyawa aktif untuk menembus EPS dari biofilm.

\section{KESIMPULAN}

Terpenoid sarang semut memiliki efek yang sama dengan klorheksidin selama 1 menit pada biofilm S. mutans, sedangkan pada 30 menit berbeda. Terdapat hubungan terpenoid isolat sarang semut dengan ekspresi mRNA ftf biofilm S. mutans ATCC 25175.

\section{DAFTAR PUSAKA}

1. Alazmah A. Early Childhood Caries: A Review. Early Child Caries A Rev J Contemp Dent Pract J Contemp Dent Pr. 2017;1818(88):1-61.

2. Widayati N. Faktor yang berhubungan dengan karies gigi pada anak. J Berk Epidemiol. 2014;2(2):196-205.

3. Khotimah K, Suhadi Ns P. Faktor-faktor yang berhubungan dengan kejadian karies gigi pada anak usia 6-12 tahun di SD Negeri Karangayu 03 Semarang. STIKES Telogorejo Semarang. 2013;014:1-10.

4. Negrini TDC, Spolidorio LC. Genetic polymorphism of Streptococcus mutans in Brazilian family members. Brazilian $\mathrm{J}$ Microbiol. 2003;34:213-7.

5. Warna D, Fatmawati A, Gigi BK, Gigi FK, Jember U. Hubungan biofilm Streptococcus mutans terhadap resiko terjadinya karies gigi. J Kedokt Gigi Univ Jember. 2011;8(3):127-30.

6. Jiang $S$, Huang $X$, Zhang $C$, Cai $Z$. Morphological and proteomic analyses of the biofilms generated by Streptococcus mutans isolated from caries-active and caries-free adults. J Dent Sci. 2015;10(2):206-15.

7. Krzysciak W, Jurczak $A$, Koscielniak D, Bystrowska B. The virulence of Streptococcus mutans and the ability to form biofilms. Eur J Clin Microbiol Infect Dis. 2014;33:499-515.

8. Jeon J, Rosalen PL, Falsetta ML, Koo H. Natural products in caries research: current (Limited) knowledge. Caries Res. 2011;45:243-63.

9. Seneviratne CJ, Zhang CF, Smaranayake LP. Dental plaque biofilm in oral health and disease. Chinese $\mathrm{J}$ Dent Res. 2011;14(2):87-94.

10. Lei L, Yang Y, Mao M, Li H, Li M, Yang $Y$, et al. Modulation of biofilm exopolysaccharides by the Streptococcus mutans vicX Gene. Front Microbilogy. December 2015;6:1-14.

11. Sato S, Kuramitsu HK. Isolation and characterization of a fructosyltransferase gene from Streptococcus mutans GS-5. Infect Immun. 1986;52(1):166-70.

12. Shemesh M, Tam A, Steinberg D. Expression of biofilm-associated genes of Streptococcus mutans in response to glucose and sucrose. J Med Microbiol. 2007;56:1528-35.

13. Li Y, Burne RA. Regulation of the gtfBC and $\mathrm{ftf}$ genes of Streptococcus mutans in biofilms in response to $\mathrm{pH}$ and carbohydrate. Soc Gen Microbiol J. 2001;147:2841-8.

14. Gartika M, Mariam MS, Kurnia D, Satari $\mathrm{MH}$. Antibacterial of terpenoid A from Sarang Semut (Myrmecodia pendans) against Streptococcus mutans. Int $\mathrm{J}$ Chemtech Res. 2018;11(01):228-33.

15. Attamimi FA, Ruslami R, Maskoen AM. 
Uji aktivitas antibakteri ekstrak kasar umbi sarang semut (Myrmecodia pendens) Streptococcus sanguinis dibandingkan Chlorhexidine. Maj Kedokt Bandung. 2017;49(2):94-101.

16. Cowan MM. Plant products as antimicrobial agents. Clin Microbiol Rev. 1999;12(4):564-82.

17. Li B, Li X, Lin H, Zhou Y. Curcumin as a promising antibacterial agent: effects on metabolism and biofilm formation in S. mutans. Biomed Res Int. 2018;1-11.

18. Gartika M, Pramesti HT, Kurnia D, Satari $\mathrm{MH}$. A terpenoid isolated from sarang semut (Myrmecodia pendans) bulb and its potential for the inhibition and eradication of Streptococcus mutans biofilm. BMC Complement Altern Med. 2018;18(151):1-8.

19. Burne RA, Chen YM, Penders JEC. Analysis of gene expression in Streptococcus mutans in biofilms in vitro. Adv Dent Res. 1997;11(1):100-9.

20. Rozen R, Bachrach G, Bronshteyn M, Gedalia I, Steinberg D. The role of fructans on dental biofilm formation by Streptococcus sobrinus, Streptococcus mutans, Streptococcus gordonii and Actinomyces viscosus. FEMS Microbiol Lett. 2001;195:205-10.

21. Rozen R, Steinberg D, Bachrach G. Streptococcus mutans fructosyltransferase interactions with glucans. FEMS Microbiol Lett. 2004;232(1):39-43.

22. Lee SF, Delaney GD, Elkhateeb M. A Two-component covRS regulatory System regulates expression of fructosyltransferase and a novel extracellular carbohydrate in Streptococcus mutans A two- component covRS regulatory system regulates expression of fructosyltransferase and a novel extracellular. $\mathrm{Am}$ Soc Microbiol. 2004;72(August 2004):3968-73.

23. Milward $P$, Jacques $A$. Secretion of fructosyltransferase by Streptococcus salivarius involves the sucrosedependent release of the cell-bound form. J Gen Microbiol. 1990;136(May):165-9.

24. Pabst J, Cisar OTL. The cell wallassociated levansucrase of actinomyces viscosus. Biochim Biophys Acta. 1979;566:274-82.

25. Abranches J, Nascimento MM, Zeng L, Browngardt CM, Wen ZT, Rivera MF, et al. CcpA regulates central metabolism and virulence gene expression in Streptococcus mutans. J Bacteriol. 2008;190(7):2340-9.

26. Abdul-aziz MH, Roberts JA, Lipman J, Mouton JW, Hope WW. Applying pharmacokinetic/Pharmacodynamic principles in critically III patients: optimizing efficacy and reducing resistance development. Thieme Med Publ. 2015;36:136-53.

27. Richards GA, Bch MB, Sa FCP, Joubert IA, Bch MB, Sa DA, et al. Optimising the administration of antibiotics in critically ill patients. South African Med J. 2015;105(5):1-5.

28. Ariningtyas E, Hemiawati SM, Laksono B. Perbedaan potensi antibakteri ekstrak metanol umbi sarang semut (Myrmecodia pendens Merr \& Perry) dan $\mathrm{NaOCl}$ terhadap Streptococcus mutans (ATCC 25175). J Kedokt Gigi. 2016;28(2):1-7. 